\title{
Bør gravide avstå fra enhver bruk av nikotin?
}

I omgang med jevngamle kolleger har jeg tenkt på hvilken faglig utvikling som har gjort sterkest inntrykk på meg i min tid. Som allmennlege og samfunnsmedisiner holder jeg gjerne frem endringen i tobakksskadeloven (røykeloven) fra 2004 (1) som det mest betydningsfulle tiltak for folkehelsen. Dette håper jeg gjenspeiles i min anmeldelse av biografien til sir Richard Doll (1912-2005) (2). Der påpekte jeg unnlatelsessynden Kungliga Vetenskapsakademien gjorde seg skyld i ved konsekvent å forbigå 1900-tallets fremste epidemio$\log$ i tildelingen av nobelprisen. Dolls sentrale forskning var knyttet til en langvarig prospektiv studie av engelske legers røykevaner (3). Den viste at sigaretter var forbundet med størst negativ helseeffekt, men at verken sigarer eller pipetobakk kunne frikjennes. Helserisikoen hang sammen med bruken av tobakk, det var kun graden og omfanget av nikotineksponeringen via luftveiene som var forskjellig.

Det siste kan ha medvirket til resultatene i Rygh og medarbeideres studie i dette nummer av Tidsskriftet (4). De har analysert bruken av snus og røyketobakk hos fødende ved Sykehuset Sørlandet i perioden 2012-14, til sammen over 10000 kvinner. Det var en klart større andel som røykte enn som snuste. Andelen røykere var også høyere enn i landet som helhet. Den var stabil i hele perioden, og sammenhengen med andre negative svangerskapsfaktorer, som sosioøkonomiske kjennetegn og livsstilskarakteristika, var som ventet. Det var likevel en tydelig nedgang $i$ tobakksbruken frem mot fødselen. Under $5 \%$ av kvinnene snuste, men bruken økte klart i løpet av perioden. Flere yngre kvinner brukte snus, og den sosioøkonomiske gradienten var langt fra så tydelig som hos røykerne. I motsetning til hypotesen var det en betydelig større andel som la bort snusen mot slutten av svangerskapet enn andelen som sluttet å røyke. Fødselsvekten var signifikant lavere hos barna til dem som røykte i siste trimester, mens det var ingen tilsvarende effekt av snusbruk. Apgarskåren var upåvirket av både tobakksrøyking og snusing (4).

Som allmennlege i en nyetablert bydel i Trondheim fra midten av 1970-årene hadde jeg mange gravide til kontroll. Interessen skjøt fart da det rundt 1980 ble innført en standardisert svangerskapsjournal (kalt Gravidogram) for hele landet. I den hadde opplysninger om kvinnens røykevaner en viktig plass. På dette tidspunkt lå prevalensen av dem som røykte i svangerskapet på rundt eller over $30 \%$, blant annet avhengig av alder og paritet. Heldigvis er situasjonen endret - med en nedgang til rundt $10 \%$ i tidsrommet frem til endringen av røykeloven (5). Senere har den gått enda lenger ned. Men som for antall døde i trafikken kan bare en nullvisjon aksepteres.

Mannen bak hypotesen «the fetal origin of adult disease», David Barker, døde i 2013. I sin omtale av Barker drøfter den danske epidemiologen Jørn Olsen deres felles forståelse av «en røykeepidemi blant vestlige gravide kvinner i perioden 1960-2000» (6). Olsen fremhever at effekten på barnet langt fra er over etter at det har forlatt det intrauterine røykerommet. Siden midten av 1980-årene har jeg medvirket til en prospektiv studie med gravide der oppfølgingen av barna fortsatt pågår (7). Den opprinnelige hensikten var å studere faktorer som hemmer fosterveksten og fører til at barnet er lettere enn forventet ved fødselen (small for gestational age, SGA), dernest effekten av dette på kort og på lang sikt. Et hovedfunn var at ingen enkeltfaktor kan måle seg med den negative effekten av tobakksrøyking på fødselsutfallet, uansett hvilke andre risikofak- torer som foreligger (7). Ett eksempel på at effekten av mors røykevaner ikke stanser ved fødselen, er at disse barna oftere enn andre er overvektige (8). Spørsmålet er hvorvidt dette henger sammen med ulike kostvaner hos mødrene $(7,9)$ eller er uavhengig av både det og fødselsvekten. I tråd med rådende hypoteser går tanken blant annet i retning av epigenetisk påvirkning i fosterlivet (10). Det kan innebære at røyking for eksempel påvirker DNA-metyleringen og endrer hvordan barnets gener avleses.

Hvordan stiller dette seg i forhold til at Rygh og medarbeidere fant at røyking - men ikke snusing - førte til lavere fødselsvekt hos barnet (4)? Deres funn stemmer overens med resultatene i to tidligere studier der man ikke fant en like uttalt effekt av snus som av røyking. Derimot viste en langt større populasjonsbasert svensk studie av nyere dato økt forekomst av barn som var små ved fødselen (4). Til tross for sine funn uttrykker Rygh og medarbeidere derfor bekymring for effekten av snus, blant annet på grunnlag av argumentet om at nikotin som absorberes fra snus, elimineres langsommere fra blodbanen enn nikotin som inhaleres. De kan også ha gått glipp av en sann effekt av to grunner. Først og fremst gikk antallet som brukte snus eller tobakk ned mot slutten av svangerskapet, men det gjorde også andelen som svarte på spørsmålet.

Er snusing et potensielt folkehelseproblem? På bakgrunn av «føre var»-prinsippet kan det umulig være snusfornuftig å karakterisere snus som en miljøgift på linje med andre nikotinholdige produkter. Og agere deretter.

\section{Geir W. Jacobsen}

geir.jacobsen@tidsskriftet.no

Geir W. Jacobsen (f. 1945) er medisinsk redaktør i Tidsskriftet og professor emeritus ved Norges teknisk-naturvitenskapelige universitet, Trondheim. Forfatter har fylt ut ICMJE-skjemaet og oppgir ingen interessekonflikter.

\section{Litteratur}

1. Lov om vern mot tobakksskader (tobakksskadeloven). https://lovdata.no/ dokument/NL/lov/1973-03-09-14 (§§ 25-29) (31.8.2016).

2. Jacobsen GW. Engelsk på ekte vis. Tidsskr Nor Legeforen 2011; 131: 729 .

3. Keating C. Smoking kills. The revolutionary life of Richard Doll. Oxford: Signal Books, 2009

4. Rygh E, Gallefoss F, Reiso H. Bruk av snus og røyketobakk hos gravide i Agder Tidsskr Nor Legeforen 2016; 136: 1351-4.

5. Øien T, Storrø O, Jenssen JA et al. The impact of a minimal smoking cessation intervention for pregnant women and their partners on perinatal smoking behaviour in primary health care: a real-life controlled study. BMC Public Health 2008; 8: 325-34

6. Olsen J. David Barker (1938-2013) - a giant in reproductive epidemiology. Acta Obstet Gynecol Scand 2014: 93: 1077-80.

7. Kjøbli E, Bach R, Skogseth $\mathrm{H}$ et al. The Scandinavian Small-for-Gestational Age (SGA) pregnancy and birth cohort - a source to continual insight into fetal growth restriction and long term physical and neurodevelopmental health in mother and offspring. Nor Epidemiol 2016; 26: 145-54

8. Rückinger S, Beyerlein A, Jacobsen $\mathrm{G}$ et al. Growth in utero and body mass index at age 5 years in children of smoking and non-smoking mothers. Early Hum Dev 2010; 86: 773-7.

9. Trygg K, Lund-Larsen K, Sandstad B et al. Do pregnant smokers eat differently from pregnant non-smokers? Paediatr Perinat Epidemiol 1995; 9: 307-19.

10. Benestad H. Mors vaner i svangerskapet har langvarig effekt på fosteret. Tidsskr Nor Legeforen 2016; 136: 1208. 